\title{
Indicators of the Internal Environment of Beef Cattle during Fattening and their Correlation to the Quality of Beef
}

\author{
A. PAVLÍK ${ }^{1}$, R. FILIPČÍK ${ }^{2}$, P. JELÍNEK ${ }^{1}$, M. BJELKA ${ }^{3}$, Z. HAVLÍČEK ${ }^{1}$, J. S̆UBRT $^{2}$ \\ ${ }^{1}$ Department of Animal Morphology, Physiology and Genetics, Mendel University of Agriculture and Forestry, \\ Brno, Czech Republic \\ ${ }^{2}$ Department of Animal Breeding, Mendel University of Agriculture and Forestry, Brno, Czech Republic \\ ${ }^{3}$ Department of Breeding and Reproduction, Research Institute for Cattle Breeding, Ltd., Vikyrovice, \\ Czech Republic \\ Received September 25, 2007 \\ Accepted June 11, 2008
}

\begin{abstract}
Pavlík A., R. Filipčík, P. Jelínek, M. Bjelka, Z. Havlíček, J. Šubrt: Indicators of the Internal Environment of Beef Cattle during Fattening and their Correlation to the Quality of Beef. Acta Vet. Brno 2008, 77: 539-546.

The objective of the study was to determine selected indicators of the internal environment in individual cattle categories during the period of fattening to evaluate the relation of the individual blood components to the growth intensity and qualitative indicators of the meat. The trial involved half-siblings - bulls, heifers and steers housed in one stable. The threesome always had a common father. During the trials the live weight was monitored and blood samples were taken on days $310,403,448,479,512,554$ and 618 of age. The concentrations of total proteins, glucose, total cholesterol, urea and catalytic concentrations of ALP, ALT, AST, calcium, inorganic phosphorus, magnesium and copper in the blood plasma were assessed. In all cases the levels of indicators of the internal environment were within the range of the physiological values for the respective age category. Compared to bulls and steers, the concentration of total plasma cholesterol of the heifers was significantly higher ( $p<0.05$ and $p<0.01$, respectively). The last samples were taken prior to slaughter of the animals and the individual components were correlated with the nutritional values and meat indicators; the correlation between the amount of glucose and urea in the blood serum and the tenderness of the meat was significant $(p<0.05$ and $p<0.01)$. The correlation between the concentration of proteins in the blood plasma, the level of nitrogen or total protein in the muscles, the water-holding capacity and meat tenderness was positive. The study provides a basis for implementing helpful adjustments in current cattle management practises. Blood indicators presented in this paper can be added to existing knowledge to benefit veterinary research and clinical evaluations.
\end{abstract}

Growth, cattle, blood, enzymes, total proteins, glucose, phosphorus, magnesium, copper, cholesterol, water-binding capacity, shearing tests

The gradually increasing milk efficiency of dairy cows in the Czech Republic and the quota limitations in milk production resulted in reductions in the numbers of dairy cows and in the total number of reared cattle. One of the options of how to maintain the numbers of cattle in the country is to rear cows that do not produce market milk. Therefore beef cattle breeds are increasingly reared. An important aspect when extending this type of rearing is to be aware of the effect of the breeding conditions on the animals and to ensure their good health, optimal efficiency expressed by their growth capacity with regard to the production of the required amount and quality of animal products. If we are to create optimal conditions that would correspond to the current requirements of individual animals, we must draw as much information as possible about the internal environment, which reflects these effects and, above all, indicates the level of nutrient, mineral and vitamin supply required, which at the same time shows the functional condition of the animal. Changes in haematological and biochemical blood indicators of various cattle categories are well known (Dubreuil and Lapierre 1997; Parra et al. 1999; Whitaker et al. 1999;

Address for correspondence:

Aleš Pavlík, Department of Morphology,

Physiology and Genetics, Mendel University

of Agriculture and Forestry,

Zemědělská 1, 61300 Brno, Czech Republic
Phone: +420 545133148

Fax. +420 545212044889

E-mail:pavlik@mendelu.cz

http://www.vfu.cz/acta-vet/actavet.htm 
Knowles et al. 2000; Jorritsma et al. 2003; Kumar and Pachauri 2000; Accorsi et al. 2005; Cavestany et al. 2005; Fontaneli et al. 2005). However, the authors mostly focus on evaluations of the internal environment of dairy cattle breeds, or some categories of cattle intended for fattening. The objective of the present study was to characterise the changes in indicators of the internal environment in the process of production of slaughter cattle (bulls, heifers and steers in the course of fattening) and to evaluate the correlations between these components and selected qualitative meat indicators.

\section{Materials and Methods}

The trials involved 33 half siblings of cattle (11 bulls, 11 heifers and 11 steers) of the Czech Fleckvieh breed (maternal position), the Charolaise, Galoway, Beef Simmental breeds, and three- and four-breed hybrids $50 \mathrm{Ch} 25 \mathrm{C} 25 \mathrm{~A}, 50 \mathrm{MS} 12,5 \mathrm{H} 12,5 \mathrm{Sh} 25 \mathrm{Ch}$. The animals were reared as cattle without commercial milk production and they were selected for the investigations on the basis of their date of birth to ensure minimal age differences. After the end of the grazing period they were transferred to the stable where groups were formed based on sex. Each group was housed on deep litter in $12 \times 12 \mathrm{~m}$ pens. During the experiment the animals were fed a mixed feed ration based on maize silage, clover-grass hay, hay (dry matter $39.14 \%$; CP $106.6 \mathrm{~g} \cdot \mathrm{kg}^{-1}$; fibres $223.3 \mathrm{~g} \cdot \mathrm{kg}^{-1}$;

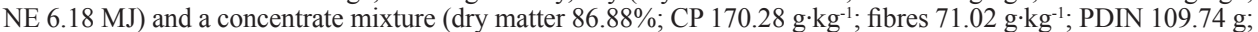
PDIE 92.69 g; NE 6.84 MJ; ME 12.03 MJ). Owing to the ventilation of the stable the micro-climate conditions were based on the climate conditions of this submontane region of the Jeseníky Mts. On days 310, 403, 448, $479,512,554$ and 618 of age the live body mass of the animals was determined and samples of blood were taken from the subcaudal vein. Immediately after the sampling using the AVL Critical Care Analyser (OPTIMedical, USA) the basic variables of the acid-base balance of blood $\left(\mathrm{pH}\right.$, partial pressure of carbon dioxide - $\mathrm{pCO}_{2}$, standard bicarbonate - SBC, base excess - BE) were determined as the indicators of the current state of balance of the processes of uptake, formation and excretion of acids and bases in the organism. The average values for the entire group of animals was as follows: $\mathrm{pH}-7.419 \pm 0.008 ; \mathrm{pCO}_{2}-6.21 \pm 0.181 \mathrm{kPa}$; $\mathrm{SBC}-27.8 \pm 0.332$ $\mathrm{mmol} \cdot \mathrm{l}^{-1} ; \mathrm{BE}-4.3 \pm 0.301 \mathrm{mmol} \cdot \mathrm{l}^{-1}$. Non-coagulating blood stabilised with EDTA was centrifuged at $1600 \times g$ for $20 \mathrm{~min}$ and the plasma was kept at $-20{ }^{\circ} \mathrm{C}$ until analysis. The blood plasma was analysed for the content of total proteins (TP), glucose (Glu), total cholesterol (Chol), urea, catalytic concentrations of alkali phosphatase (ALP), alanine amino transferase (ALT), aspartate transaminase (AST), calcium (Ca), inorganic phosphorus (Pi), magnesium $(\mathrm{Mg})$ and copper $(\mathrm{Cu})$. The analysis was performed by spectrometry on the Cobas Mira Plus automatic analyser (Roche, Switzerland) using available commercial sets (Biovendor a.s., Czech Republic). The growth rate during fattening was evaluated by calculating the average weight gains (WG) in given time intervals between the individual samplings. After the termination of fattening the animals were slaughtered and a sample of the musculus longissimus et thoracis was taken at the level of the halving cut between the $9^{\text {th }}$ and $10^{\text {th }}$ thoracic vertebra for laboratory analysis. The laboratory analyses were conducted $48 \mathrm{~h}$ post mortem according to the Czech norm ČSN 570185 in the biotechnological laboratory of the Department of Animal Breeding of Mendel University of Agriculture and Forestry in Brno. The water content was determined by pre-drying the meat sample $(5 \mathrm{~g})$ with sand for 2 hours at $60^{\circ} \mathrm{C}$ followed by drying for $5-7$ hours at $103{ }^{\circ} \mathrm{C}$ and assessing the weight loss. The protein content was determined using the method of Kjeldahl, the fat content by extraction with diethyl ether for 6 hours in an extension of Soxhlet's apparatus, the ash content by burning in a furnace at $550-600{ }^{\circ} \mathrm{C}$ for 8 hours, freely bound water was determined applying the modified pressing method according to Grau and Hamm (1953). The tenderness of the meat was evaluated in the laboratory of the Department of Food Technology of the Mendel University of Agriculture and Forestry in Brno by a shearing test according to the methods of Christensen et al. (2000).

Statistical interpretation of the data was conducted in the statistical package SAS 9.1.3. To determine the effect of age and sex on the indicators of the internal environment we used the two-way analysis of variance with repeated measures and the differences among the respective categories by post hoc tests using Fisher's LSD test. The dependence of indicators of the metabolic and mineral profile on age and growth intensity expressed by the weight gain was evaluated using correlation analysis at a level of significance $(p<0.05)$. Correlations between the internal environment and meat quality were performed by analysis of variance as follows:

$\mathrm{Y}_{\mathrm{ijk}}=\mu+\mathrm{TP}_{\mathrm{i}}+\mathrm{U}_{\mathrm{j}}+\mathrm{G}_{\mathrm{k}}+\mathrm{e}_{\mathrm{ijk}}$

where: TP - total proteins: $1-<70.00 \mathrm{~g} \cdot \mathrm{l}^{-1} ; 2->70.01 \mathrm{~g} \cdot \mathrm{l}^{-1}$

$\mathrm{U}$ - urea: $1-<2.00 \mathrm{mmol} \cdot \mathrm{l}^{-1} ; 2->2.01 \mathrm{mmol} \cdot \cdot^{-1}$

$\mathrm{G}$ - glucose: $1-<5.00 \mathrm{mmol} \cdot \mathrm{l}^{-1} ; 2->5.01 \mathrm{mmol} \cdot \mathrm{l}^{-1}$

\section{Results}

In the fattening period from 310 to 618 days of age the highest weight gains were found in bulls (Fig. 1). In the first half of this period the differences among the groups were significant $(p<0.05)$. The lowest weight gains were in heifers. During this period the total proteins in the blood plasma did not change considerably (Table 1), showing a slight increase at the 


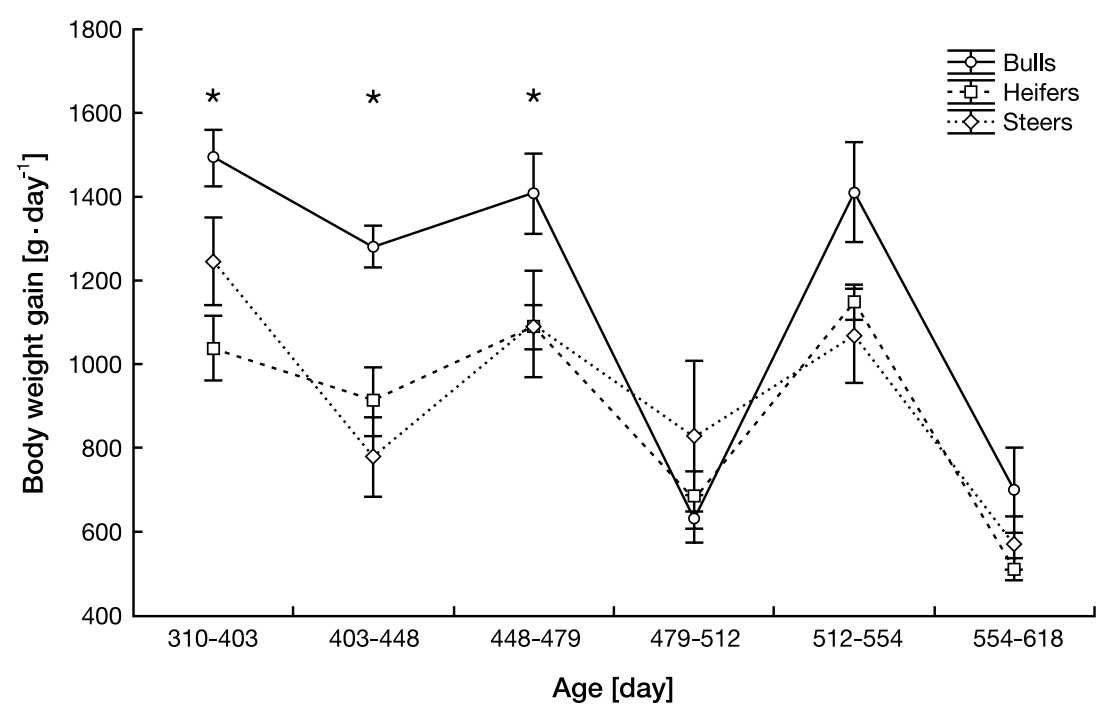

Fig. 1. Average daily body weight gains $\left(\mathrm{g} \cdot \mathrm{day}^{-1}\right)$ in the period between days 310 and 618 of age in the individual categories of animals. The data represent the mean $\pm \mathrm{SEM}$; * represents $p<0.05$.

Table 1. Values of selected indicators of the internal environment of bulls, heifers and steers during fattening.

The data represent the mean \pm SEM for the entire experiment from days 310 to 618 of age. $P$ - probability.

\begin{tabular}{|c|c|c|c|c|c|c|}
\hline \multirow{2}{*}{ Indicator } & Bulls & Heifers & Steers & \multicolumn{3}{|c|}{$P$} \\
\hline & mean SEM & mean SEM & mean SEM & sex & time & sex $\times$ time \\
\hline WG $\left[\mathrm{g} \cdot \mathrm{day}^{-1}\right]$ & $1153.7 \pm 81.4$ & $894.8 \pm 58.1$ & $931.1 \pm 114.1$ & $<0.001$ & $<0.001$ & 0.227 \\
\hline $\mathrm{TP}\left[\mathrm{g} \cdot \mathrm{1}^{-1}\right]$ & $69.46 \pm 0.60$ & $71.02 \pm 0.51$ & $69.25 \pm 0.50$ & 0.426 & $<0.001$ & 0.025 \\
\hline Glu $\left[\mathrm{mmol} \cdot \mathrm{l}^{-1}\right]$ & $4.80 \pm 0.08$ & $4.86 \pm 0.08$ & $4.79 \pm 0.07$ & 0.671 & 0.006 & 0.041 \\
\hline Chol $\left[\mathrm{mmol} \cdot \mathrm{l}^{-1}\right]$ & $2.05 \pm 0.06$ & $2.59 \pm 0.06$ & $2.06 \pm 0.04$ & 0.003 & $<0.001$ & $<0.001$ \\
\hline Urea $\left[\mathrm{mmol} \cdot \mathrm{l}^{-1}\right]$ & $2.82 \pm 0.15$ & $3.16 \pm 0.13$ & $2.78 \pm 0.14$ & 0.837 & $<0.001$ & 0.038 \\
\hline $\operatorname{ALP}\left[\mu \mathrm{katl} \cdot 1^{-1}\right]$ & $2.81 \pm 0.23$ & $2.06 \pm 0.14$ & $2.10 \pm 0.14$ & 0.052 & 0.042 & 0.003 \\
\hline ALT $\left[\mu \mathrm{katl} \cdot 1^{-1}\right]$ & $0.49 \pm 0.02$ & $0.58 \pm 0.02$ & $0.54 \pm 0.02$ & 0.035 & $<0.001$ & 0.049 \\
\hline AST $\left[\mu \mathrm{katl}^{-1} \mathrm{l}^{-1}\right]$ & $1.67 \pm 0.08$ & $1.53 \pm 0.06$ & $1.33 \pm 0.03$ & 0.207 & $<0.001$ & 0.002 \\
\hline $\mathrm{Ca}\left[\mathrm{mmol} \cdot \mathrm{l}^{-1}\right]$ & $2.42 \pm 0.03$ & $2.49 \pm 0.03$ & $2.48 \pm 0.02$ & 0.026 & $<0.001$ & 0.167 \\
\hline $\mathrm{Pi}\left[\mathrm{mmol}^{-1} \mathrm{l}^{-1}\right]$ & $2.50 \pm 0.04$ & $2.40 \pm 0.03$ & $2.50 \pm 0.03$ & 0.106 & 0.002 & 0.047 \\
\hline $\mathrm{Mg}\left[\mathrm{mmol} \cdot \mathrm{l}^{-1}\right]$ & $0.89 \pm 0.02$ & $0.88 \pm 0.02$ & $0.93 \pm 0.02$ & 0.292 & $<0.001$ & 0.015 \\
\hline $\mathrm{Cu}\left[\mu \mathrm{mol} \cdot \mathrm{l}^{-1}\right]$ & $10.95 \pm 0.31$ & $11.46 \pm 0.31$ & $11.03 \pm 0.29$ & 0.956 & 0.005 & 0.068 \\
\hline
\end{tabular}

end of the experiment in all groups. The content of total proteins on days 479 and 554 of age was higher $(p<0.05)$ in heifers than in bulls. No marked changes were detected in the concentration of plasma glucose either. Non-significantly lower concentrations, particularly in the second half of trial, occurred in bulls. The concentration of glucose increased $(p<0.05)$ at the end of the fattening period in heifers and steers as compared with bulls. The concentration of total cholesterol fluctuated in all animals, being highest in heifers (except for day 310 of age, see Fig. 2). At the age of 403, 479, and 554 days these differences compared to bulls and steers were significant $(p<0.01)$. In the other cases the differences were significant $(p<$ $0.05)$. During the experiment urea fluctuated in all groups. Its concentrations were the highest on day 554 of age. Using Fisher's post-hoc test we found that the average concentration of urea was lower $(p<0.05)$ in bulls compared to steers at the age of 403 days. The highest $(p<0.01)$ catalytic activity of ALP during the experiment was detected in bulls in the middle 


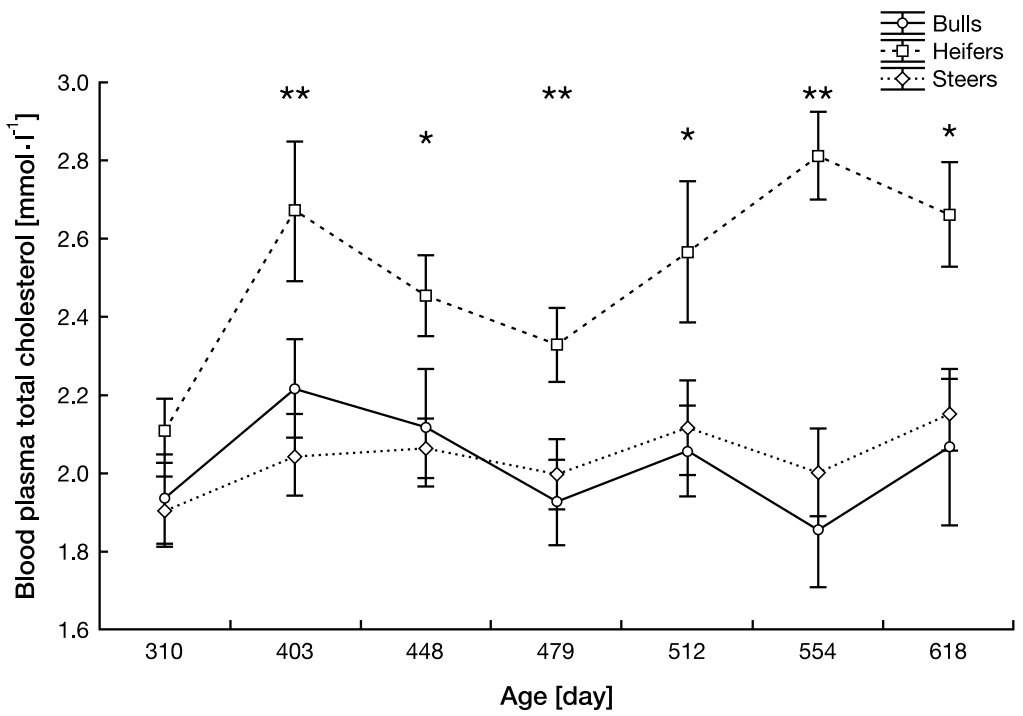

Fig. 2. Concentration of total cholesterol in blood plasma of the individual categories of animals during fattening. The data represent the mean \pm SEM. * represents $(p<0.05),{ }^{* *}$ represents $(p<0.01)$.

Table 2. Correlation between indicators of the internal environment, live weight gains and age of the animals. Values presented in bold face are significant at $p<0.05, \mathrm{n}=198$.

\begin{tabular}{|l|r|r|r|r|r|c|c|c|c|c|c|c|c|}
\hline & WG & Age & ALP & ALT & AST & Ca & Chol & Glu & Mg & Pi & Urea & TP & Cu \\
\hline WG & $*$ & $\mathbf{- 0 . 4 1}$ & 0.04 & -0.09 & -0.08 & -0.16 & $\mathbf{- 0 . 1 6}$ & $\mathbf{- 0 . 2 9}$ & 0.23 & 0.13 & $\mathbf{- 0 . 4 1}$ & $\mathbf{- 0 . 1 9}$ & -0.23 \\
\hline Age & $\mathbf{- 0 . 4 1}$ & $*$ & 0.13 & $\mathbf{0 . 3 0}$ & $\mathbf{- 0 . 3 1}$ & $\mathbf{- 0 . 4 0}$ & -0.05 & -0.22 & 0.06 & -0.01 & 0.16 & -0.12 & -0.09 \\
\hline ALP & 0.04 & \multicolumn{1}{|c|}{0.13} & $*$ & 0.01 & 0.00 & $\mathbf{- 0 . 1 8}$ & -0.06 & -0.07 & $\mathbf{- 0 . 1 7}$ & 0.02 & -0.13 & -0.06 & $\mathbf{- 0 . 2 2}$ \\
\hline ALT & -0.09 & $\mathbf{0 . 3 0}$ & 0.01 & $*$ & -0.01 & 0.00 & $\mathbf{0 . 2 7}$ & -0.02 & $\mathbf{0 . 3 2}$ & $\mathbf{- 0 . 3 6}$ & $\mathbf{0 . 3 0}$ & 0.04 & 0.04 \\
\hline AST & -0.08 & $\mathbf{- 0 . 3 1}$ & 0.00 & -0.01 & $*$ & -0.09 & 0.27 & 0.02 & 0.05 & -0.03 & -0.13 & 0.13 & 0.18 \\
\hline Ca & -0.16 & $\mathbf{- 0 . 4 0}$ & $\mathbf{- 0 . 1 8}$ & 0.00 & -0.09 & $*$ & 0.13 & $\mathbf{0 . 5 2}$ & -0.15 & -0.09 & -0.26 & $\mathbf{0 . 2 8}$ & 0.24 \\
\hline Chol & $\mathbf{- 0 . 1 6}$ & -0.05 & -0.06 & $\mathbf{0 . 2 7}$ & 0.27 & 0.13 & $*$ & -0.10 & 0.00 & -0.27 & -0.17 & $\mathbf{0 . 2 9}$ & 0.27 \\
\hline Glu & $\mathbf{- 0 . 2 9}$ & -0.22 & -0.07 & -0.02 & 0.02 & $\mathbf{0 . 5 2}$ & -0.10 & $*$ & -0.10 & -0.08 & 0.08 & $\mathbf{0 . 4 5}$ & -0.07 \\
\hline Mg & 0.23 & 0.06 & $\mathbf{- 0 . 1 7}$ & $\mathbf{0 . 3 2}$ & 0.05 & -0.15 & 0.00 & -0.10 & $*$ & -0.11 & 0.19 & 0.02 & -0.06 \\
\hline Pi & 0.13 & -0.01 & 0.02 & $\mathbf{- 0 . 3 6}$ & -0.03 & -0.09 & -0.27 & -0.08 & -0.11 & $*$ & -0.11 & $\mathbf{0 . 3 6}$ & -0.10 \\
\hline Urea & $\mathbf{- 0 . 4 1}$ & 0.16 & -0.13 & $\mathbf{0 . 3 0}$ & -0.13 & -0.26 & -0.17 & 0.08 & 0.19 & -0.11 & $*$ & $\mathbf{- 0 . 4 6}$ & -0.09 \\
\hline TP & $\mathbf{- 0 . 1 9}$ & -0.12 & -0.06 & 0.04 & 0.13 & $\mathbf{0 . 2 8}$ & $\mathbf{0 . 2 9}$ & $\mathbf{0 . 4 5}$ & $\mathbf{0 . 0 2}$ & $\mathbf{0 . 3 6}$ & $\mathbf{- 0 . 4 6}$ & $*$ & $\mathbf{0 . 4 3}$ \\
\hline Cu & -0.23 & -0.09 & $\mathbf{- 0 . 2 2}$ & 0.04 & 0.18 & 0.24 & 0.27 & -0.07 & -0.06 & -0.10 & -0.09 & $\mathbf{0 . 4 3}$ & $*$ \\
\hline
\end{tabular}

of the experimental period. With the exception of day 448 of age the average values were the lowest in the group of heifers. In the first half of the experiment the catalytic activities of ALT increased with age. The ALT activity was not considerably different among the groups; only at the age of 512 and 554 days it was higher $(p<0.05)$ in heifers than in bulls. From day 448 of age until the end of the experiment the catalytic activity of AST was higher ( $p$ $<0.05)$ in the plasma of bulls than in the plasma of heifers and steers. From the beginning of the experiment the concentration of plasma calcium was seen to decrease slightly and no significant differences were found among the groups. The phosphorus concentration did not change either; with advancing age its content slightly decreased. In single animals the difference among the respective categories was significant $(p<0.05)$, but in no group an obvious trend towards a higher or lower concentration was observed. Results similar to the 
P concentrations were found in plasma Mg. Sporadic differences $(p<0.05)$ occurred at the beginning and end of the experiment. During the whole period the mean concentrations of plasma copper decreased and did not differ among the three groups. The average value was higher $(p<0.05)$ in heifers than in the other groups on day 479 .

With advancing age the growth rate of animals decreased (Table 2). This dependence is expressed by the value of the correlation coefficient: -0.41 . A low significant correlation intensity of the weight gains was discovered in relation to the concentration of total proteins, total cholesterol and glucose. A mean dependence of the gains $(-0.41)$ was detected in relation to the concentration of plasma urea of the animals. A correlation between the age of animals and indicators of the internal environment was confirmed for ALT (0.30), AST $(-0.31)$ and $\mathrm{Ca}(-0.40)$.

Table 3. Effect of the concentration of total plasma proteins on the qualitative indicators of meat

\begin{tabular}{|c|c|c|c|c|c|c|c|}
\hline \multicolumn{2}{|c|}{ Blood plasma indicator } & \multicolumn{6}{|c|}{ Qualitative meat indicators } \\
\hline \multirow{8}{*}{ Total protein } & \multirow{2}{*}{ Range } & \multicolumn{2}{|c|}{ Nitrogen $(\%)$} & \multicolumn{4}{|c|}{ Total protein } \\
\hline & & LS mean & SD & $P$ & LS mean & SD & $P$ \\
\hline & $<70.00$ & 3.42 & 0.12 & \multirow{2}{*}{0.05} & 21.40 & 0.74 & \multirow{2}{*}{0.05} \\
\hline & $>70.01$ & 3.35 & 0.15 & & 21.04 & 0.89 & \\
\hline & \multirow{2}{*}{ Range } & \multicolumn{2}{|c|}{ Binding capacity of water $(\%)$} & & \multicolumn{3}{|c|}{ TPA $1 *\left(\mathrm{~N} / \mathrm{cm}^{2}\right)$} \\
\hline & & LS mean & SD & $P$ & LS mean & SD & $P$ \\
\hline & $<70.00$ & 78.47 & 2.46 & \multirow{2}{*}{0.05} & 169.67 & 122.87 & \multirow{2}{*}{0.01} \\
\hline & $>70.01$ & 76.82 & 1.76 & & 239.25 & 149.96 & \\
\hline
\end{tabular}

*TPA 1 - force required to press a $1 \times 1 \times 1 \mathrm{~cm}$ meat sample down to $70 \%$ of its thickness $\left(\mathrm{N} / \mathrm{cm}^{2}\right)$

Out of all the indicators under study, a correlation was found (Table 3 ) between the proportion of total plasma proteins and the amount of nitrogen, or total proteins of beef at a $95 \%$ level of probability; the values of nitrogen ranged in mean values of $2.95 \pm 0.12 \%$ (at a plasma protein concentration under $70.00 \mathrm{~g} \cdot \mathrm{l}^{-1}$ ) and $3.52 \%$ (concentration of plasma protein above $70.01 \mathrm{~g} \cdot \mathrm{l}^{-1}$, the difference being $\pm 0.15 \%$ ). The amount of total protein in muscles ranged between $18.42 \pm \%$ and $21.98 \%$. The concentration of plasma proteins was correlated with the most important technological properties of meat - its water-binding capacity. Lower concentrations of total plasma proteins were positively correlated $(p<$ $0.05)$ with a higher water-binding capacity and also with a higher tenderness of meat $(p<$ 0.01 ), or to a lower force necessary to grind meat (TPA $1: 169.67 \mathrm{~N}$ at a content of total plasma proteins of less than $70.00 \mathrm{~g} \cdot \mathrm{l}^{-1}$ against $239.25 \mathrm{~N}$ at a content of plasma proteins above 70.01). The tenderness of meat evaluated by means of shearing tests (Table 4 ) was affected by the urea and glucose concentrations ( $p<0.01$ and $p<0.01$, respectively). Lower concentrations of urea and glucose (no more than $2.00 \mathrm{mmol} \cdot \mathrm{l}^{-1}$ and $5.00 \mathrm{mmol} \cdot \mathrm{l}^{-1}$, respectively) in the plasma had a positive effect on forces necessary to cut through the muscle fibres $(123.16 \pm 22.9 \mathrm{~N}$ (urea), $125.32 \pm 23.22 \mathrm{~N}$ (glucose).

Table 4. Effect of the concentration of plasma urea and glucose on the qualitative indicators of meat

\begin{tabular}{|c|c|c|c|c|}
\hline \multirow{4}{*}{ Urea } & \multirow{2}{*}{ Range } & \multicolumn{3}{|c|}{ Shearing force $(\mathrm{N})$} \\
\hline & & LS mean & SD & $P$ \\
\hline & $<2.00$ & 123.16 & 22.99 & \multirow{2}{*}{0.01} \\
\hline & $>2.01$ & 142.20 & 15.77 & \\
\hline \multirow{4}{*}{ Glucose } & \multirow{2}{*}{ Range } & \multicolumn{3}{|c|}{ Shearing force $(\mathrm{N})$} \\
\hline & & LS mean & SD & $P$ \\
\hline & $<5.00$ & 125.32 & 23.22 & \multirow{2}{*}{0.01} \\
\hline & $>5.01$ & 141.36 & 16.34 & \\
\hline
\end{tabular}




\section{Discussion}

Evaluation of variables of the metabolic and mineral profile of blood plasma are used primarily to control the animal's health condition, to identify any nutritional deficiencies and metabolic disorders of the organism. The present study describes the changes in indicators of the internal environment of beef cattle hybrids during fattening and their relation to the intensity of growth and some qualitative meat indicators. Only a few studies are currently available dealing with this topic, and comparison with other authors is difficult mostly because of the altogether different climate conditions in the Czech Republic.

The concentrations of total proteins in the blood plasma decreased slightly with the age of the animals; this could be connected with the decreasing gains, i.e. with a decreasing formation of muscle mass. However, in contrast to our results, Otto et al. (2000) reported a lower concentration of total proteins in younger age categories of the Angoni breed. In agreement with the conclusions of these authors we did not find any sex-based differences among the groups, either. The concentration of glucose was maintained by sensitive homeostatic mechanisms and therefore its sensitivity to changes in the energy balance was low (Whitaker et al. 1999) and in accordance with the inexpressive changes in the average values of plasma glucose during the experiment.

In the second half of the study the plasma glucose levels of heifers were higher, in contrast to the results of Otto et al. (2000), who reported a higher glucose concentration in bulls. During the entire experiment, the concentrations of total plasma cholesterol were significantly higher in the group of heifers with the lowest growth intensity. The increase in plasma urea fluctuated and a significant correlation dependence on the weight gains was found. The higher concentration in animals with a low intensity of growth is probably due to the surplus of nitrogenous substances taken up from the feed and not utilised in the organism primarily for the forming of muscles any more. A significant correlation dependence (-0.46) was determined also in relation to the amount of urea and content of total plasma proteins. In accordance with our results Otto et al. (2000) also found an age-dependent increase in urea content. Grunwaldt et al. (2005) reported concentrations higher than our data. The effect of the enzymes explored in our experiment was largely intracellular, i.e. under physiological conditions their catalytic activity in the plasma was very low. The increase in their activities indicated that the tissues in which they appeared were damaged. In our experiment the enzyme activity ranged within the physiological values given for these age categories of cattle. The differences among the respective groups were significant. A significant age-related correlation was also observed; this is in accordance with the findings of Roussel et al. (1982) and Otto et al. (2000). These age and sex-based differences could be associated with the different rate of nitrogen metabolism, with which these enzymes by their synthesis and amino acid degradation interfere. The concentration of mineral elements $(\mathrm{Ca}, \mathrm{P}, \mathrm{Mg})$ did not change considerably with advancing age, and sex did not have a significant effect on the level of these elements, either. In contrast, Otto et al. (2000) reported higher concentrations of $\mathrm{Ca}$ and $\mathrm{P}$ in females and younger age categories.

In our study significant correlations between some indicators of the internal environment and qualitative indicators of the meat of cattle were detected. In a similar study, Tipton et al. (2007) evaluated the correlations between the components of blood serum, or the amount of calcium and magnesium ions, and the amount of vitamin $\mathrm{D}_{3}$ and tenderness of meat of steers and heifers. They proved that the correlation between the concentration of calcium, the amount of vitamin $\mathrm{D}_{3}$ and the tenderness of meat evaluated by shearing tests was significant $(p<0.05)$. Adachi et al. (1999) evaluated the correlation between the concentration of blood serum components and marbling of meat of steers and they proved the effect of glucose concentration on meat marbling. 
All indicators of the internal environment monitored in the present study were within the physiological range for the given category and no health disorder was detected. In some cases the effect of sex on the indicators of the internal environment was reported as significant. The differences among the respective categories were apparently due to the differences in the rate of their intermediary metabolism during the experimental period. To a certain extent they also reflect the changes in the live body mass of the animals. Changes in variables of the mineral profile during the trial were probably affected by the requirements of the individual animals for the intake of these mineral elements in the feed ration due to metabolic processes during growth and development. The changes in metabolic processes may also affect the quality of meat which, however, is also affected by a number of other factors. Our study indicates a correlation between the content of plasma proteins and amount of proteins in meat. The concentration of plasma protein is also connected with the water-binding capacity of the meat and with its tenderness, which to a certain extent is affected by the amount of plasma glucose and urea in cattle.

\section{Ukazatelé vnitřního prostř̌edí masného skotu v průběhu výkrmu a jejich vztah ke kvalitě hovězího masa}

Cílem práce bylo stanovit vybrané ukazatele vnitřního prostředí u jednotlivých kategorií skotu v průběhu období výkrmu do 310. do 618. dne věku a zhodnotit vztah jednotlivých složek krve k růstové intenzitě a kvalitativním ukazatelům masa. Do sledování v provozní stáji byli zařazeni polosourozenci - býci, jalovice a voli. Daná trojice zvířat měla vždy společného otce. V průběhu sledovaného období byla 310., 403., 448., 479., 512., 554. a 618. den věku zjišt'ována živá hmotnost a odebírány vzorky krve. V krevní plazmě byla stanovena koncentrace celkových bílkovin, glukózy, celkového cholesterolu, močoviny, katalytické koncentrace ALP, ALT, AST, koncentrace vápníku, anorganického fosforu, hořčíku a mědi. Zjištěné hladiny indikátorů vnitřního prostředí se ve všech prrípadech nacházely v rozmezí fyziologických hodnot pro dané věkové kategorie. Signifikantně vyšší $(p<0,05$ a $p<0,01)$ koncentrace celkového cholesterolu v krevní plazmě byla zaznamenána u kategorie jalovic ve srovnání s býky a voli. Poslední odběr byl proveden před porážkou zvířat a zastoupení jednotlivých složek krve bylo vztaženo k hodnotám nutričních a technologických ukazatelů masa, kde byly zjištěny statisticky průkazné $(p<0,05$ a $p<0,01)$ závislosti mezi množstvím močoviny a glukózy v krevní plazmě ke křehkosti masa. Koncentrace bílkovin v krevní plazmě vykazovala pozitivní vztah k podílu dusíku, resp. celkového proteinu ve svalovině, k vaznosti vody a ke krrehkosti masa.

\section{Acknowledgement}

The study was supported by the grant projects IGA MZLU 25/2006 and NAZV, Czech Republic, QF 4005 and Research Plan No. MSM6215648905.

\section{References}

ACCORSI PA, GOVONI N, GAIANI R, PEZZI C, SEREN E, TAMANINI C 2005: Leptin, GH, PRL, insulin and metabolic parameters throughout the dry period and lactation in dairy cows. Reprod Domest Anim 40: 217-223

ADACHI K, KAWANO H, TSUNO K, NOMURA Y, YAMAMOTO N, ARIKAWA A, TSUJI A, ADACHI M, ONIMARU T, OHWADA K 1999: Relationship between serum biochemical values and marbling score in Japanese Black steers. J Vet Med Sci 61: 961-964

CAVESTANY D, BLANC JE, KULCSAR M, URIARTE G, CHILIBROSTE P, MEIKLE A, FEBEL H, FERRARIS A, KRALL E 2005: Studies of the transition cow under a pasture-based milk production system: metabolic profiles. J Vet Med A-Physiol Pathol Clin Med 52: 1-7

DUBREUIL P, LAPIERRE H 1997: Biochemistry reference values for Quebec lactating dairy cows, nursing sows, growing pigs and calves. Can J Vet Res-Rev Can Rech Vet 61: 235-239

FONTANELI RS, SOLLENBERGER LE, LITTELL RC, STAPLES CR 2005: Performance of lactating dairy cows managed on pasture-based or in freestall barn-feeding systems. J Dairy Sci 88: 1264-1276

GRAU R, HAMM R 1953: Eine einfache Methode zur Bestimmung der Wasserbindung in Muskel. 
Naturwissenschaften 40: 29-30

GRUNWALDT EG, GUEVARA JC, ESTEVEZ OR, VICENTE A, ROUSSELlE H, ALCUTEN N, AGUERREGARAY D, STASI CR 2005: Biochemical and haematological measurements in beef cattle in Mendoza plain rangelands (Argentina). Trop Anim Health Prod 37: 527-540

CHRISTENSEN M, PURSLOW PP, LARSEN LM 2000: The effect of cooking temperature on mechanical properties of whole meat, single muscle fibres and perimysial connective tissue. Meat Sci 55: 301-307

JORRITSMA R, WENSING T, KRUIP TA, VOS PL, NOORDHUIZEN JP 2003: Metabolic changes in early lactation and impaired reproductive performance in dairy cows. Vet Res 34: 11-26

KNOWLES TG, EDWARDS JE, BAZELEY KJ, BROWN SN, BUTTERWORTH A, WARRISS PD 2000: Changes in the blood biochemical and haematological profile of neonatal calves with age. Vet Rec 147: 593-598

KUMAR B, PACHAURI SP 2000: Haematological profile of crossbred dairy cattle to monitor herd health status at medium elevation in Central Himalayas. Res Vet Sci 69: 141-145

OTTO F, VILELA F, HARUN M, TAYLOR G, BAGGASSE P, BOGIN E 2000: Biochemical blood profile of Angoni cattle in Mozambique. Isr J Vet Med 55: 150-159

PARRA O, OJEDA A, COMBELLAS J, GABALDON L, ESCOBAR A, MARTINEZ N, BENEZRA M 1999: Blood metabolites and their relationship with production variables in dual-purpose cows in Venezuela. Prev Vet Med 38: 133-145

ROUSSEL JJ, ARANAS TJ, SEYBT SH 1982: Metabolic profiles testing in Holstein cattle in Louisiana: reference values. Am J Vet Res 43: 1658-1660

TIPTON NC, KING DA, PASCHAL JC, HALE DS, SAVELL JW 2007: Effects of oral vitamin D $_{3}$ supplementation and supplement withdrawal on the accumulation of magnesium, calcium and vitamin $\mathrm{D}$ in the serum, liver, and muscle tissue and subsequent carcass and meat quality of Bos indicus influenced cattle. Meat Sci 75: 150-158

WHITAKER DA, GODGER WJ, GARCIA M, PERERA BM, WITTWER F 1999: Use of metabolic profiles in dairy cattle in tropical and subtropical countries on smallholder dairy farms. Prev Vet Med 38:119-131 